\title{
LIDERSTVO I INTERVENCIJE U PONAŠANJU KAO PUT KA UNAPREĐENJU KULTURE SIGURNOSTI NA RADU
}

UDK 331.45:65.011

PRIMLJENO: 1.2 .2017$.

PRIHVAĆENO: 1.3 .2017$.

\begin{abstract}
SAŽETAK: Zakonskim propisima, normama, standardima, sustavima upravljanja te brojnim radnim uputama definirana su pravila sigurnog ponašanja na radu. Unatoč tome, nesreće na radu se i dalje događaju, $i$ to ponajprije zbog nepoštovanja propisanih pravila zaštite na radu.

Postavlja se pitanje zašto radnici na svim razinama unatoč saznanjima o pravilima zaštite na radu i dalje odabiru ponašati se na nesiguran način.

Što je potrebno poduzeti kako bi se utjecalo na promjenu ponašanja sudionika u procesu rada, zatim zajednice u kojoj oni rade i djeluju te naposljetku onoga što se naziva "kulturom u zaštiti na radu"?

Autori u radu objašnjavaju model ponašanja, karakteristike posljedica našeg ponašanja te ulogu vođe u nastanku pozitivnih promjena u ophođenju prema sigurnosti na radu. Nadalje, predstavljaju se alati korišteni u kampanjama s ciljem promicanja sigurnog ponašanja s posebnim težištem na važnost interveniranja kod uočenih nesigurnih ponašanja i/ili nesigurnih situacija.
\end{abstract}

Ključne riječi: ponašanje u sigurnosti, vođa, intervencija

\section{UVOD}

Promicanje pozitivnog ponašanja prema sigurnosti na radu - pod kojim terminom podrazumijevamo jedinstvo tri pojma "Zaštita zdravlja, Zaštita na radu i Zaštita okoliša", odnosno sveobuhvatnost engleskog termina "Health Safety and Environment" (HSE) - važan je dio upravljanja sustavima sigurnosti i promjene na bolje onoga što se naziva "kultura zaštite na radu". No, što se podrazumijeva pod kulturom? Ako se pojam „kultura" potraži u rječniku hrvatskog jezika, dobit će se definicija da je kultura "cjelokupno društveno nasljeđe neke grupe ljudi, to jest

*Mr. sc. Frano Mika, dr. med., (frano.mika@saipem.com), Antonia Deković, struč. spec., ing. sig., SAIPEM S.p.A. podružnica u Republici Hrvatskoj, Alda Colonnella 2, 51000 Rijeka, Hrvatska, Andrea Forzan, ing., Saipem SpA, Via Maritiri di Cefalonia 67, 20067 S. Donato Milanese (MI), Italia, doc. dr. sc. Sandra Pavičić Žeželj, Nastavni zavod za javno zdravstvo PGŽ, Krešimirova 52A, 51000 Rijeka. naučeni obrasci mišljenja, osjećanja i djelovanja neke grupe, zajednice ili društva, kao i izrazi tih obrazaca u materijalnim objektima", odnosno kolektivnim konsenzusom koji polako, potiho, ali stalno uobličuju nas i naše ponašanje. Kraće rečeno, kultura se može definirati kao ono kako ovdje radimo, kako se ovdje ponašamo!

Za razliku od "klime zaštite na radu“, koja predstavlja trenutačan osjećaj, raspoloženje o stanju zaštite na radu u određenom okruženju, kultura zaštite na radu predstavlja dugoročan odnos i zajedničku fokusiranost, razmišljanjima i djelima, spram sigurnosti na radu unutar organizacije te postavljanje iste kao prioriteta (Deal with it training, 2017.).

Kao i svaka kultura, tako se i kultura zaštite na radu mijenjala kroz vrijeme. Sjetimo se samo dobro poznate fotografije koju je 1932. godine 
tijekom izgradnje Reckeffelerovog tornja u New Yorku fotografirao Charles Ebbets, a na kojoj radnici mirno sjede i odmaraju na jednoj od čeličnih greda postavljenoj na velikoj visini bez ikakve zaštite od mogućega pada. Nije to bilo u to doba ništa posebno, jer dok ih je snimao i sam fotograf bio je u sličnom položaju. Jednostavno, to je u to doba bilo kulturološki prihvatljivo! No, nasreću kultura zaštite na radu se promijenila i još se mijenja. Iz faze potpunog zanemarivanja s početka industrijske revolucije prošla je kroz reaktivnu fazu, zasnovanu na iskustvima i posljedicama velikih nesreća (npr. one Titanica nakon koje su uvedene norme Safety of Life at Sea - SOLAS), da bi preko preventivne faze, one nakon nesreće plaltforme "Piper Alfa", zasnovane na procesu koji uvodi procjenu rizika, integraciju sustava HSE, definiranje neophodnih znanja i vještina iz zaštite na radu svakog pojedinca uključenog $u$ proces rada, izradu dokumentacije, radnih uputa, procedura, znakove sigurnosti, osposobljavanja, audite, sastanke, prezentacije, kampanje i sl., došli do one današnje u kojoj razina zaštite u suvremenom industrijskom procesu ovisi o kulturi zaštite na radu, odnosno o ponašanju svakog pojedinca u sustavu, njegovoj osobnoj odgovornosti, stavu i sposobnosti da vodi i predvodi u zaštiti na radu.

No, što stvara kulturu zaštite na radu? U svakom slučaju prvi i osnovni uvjet jest, osim postojanja dobrog sustava sigurnog radnog okruženja, kako se radnici odnose prema sigurnosti. Nesreće na radu uzrokovane su većinom nesigurnim ponašanjem sudionika u nekom dijelu procesa izvršenja radnih zadataka. Industrijsko okruženje naišlo je na tzv. "plato“ broja nesreća na radu gdje je unatoč mnogim naporima njihova pojava i dalje prisutna. Isto tako dugoročna, mo- notona i jednakoobrazna primjena tradicionalnog pristupa dovodi do zasićenja i indiferentnosti prema sigurnosti na radu kako radnika tako i rukovodstva.

Što učiniti kako sigurnost na radu ne bi postala olako shvaćena? Zašto se djelatnici, pa i rukovodioci, svjesno ili nesvjesno, odlučuju ponašati na nesiguran način i kako utjecati na njihovo ponašanje?

\section{ABC MODEL PONAŠANJA}

Kako bi se našao način da se učinkovito utječe na promjenu ponašanja svih radnika, važno je prije svega razumjeti glavne čimbenike koji utječu na to zašto se ljudi u određenom trenutku ponašaju na određen način. Neki od njih su stav rukovoditelja i radnika, uspostavljeni sustav vrijednosti, uvjerenja, motivacija, osobnosti i percepcija okruženja u kojemu se živi i radi. Osobni čimbenici koji utječu na ponašanje jesu odgoj, dosadašnje iskustvo, okolina u kojoj se živi i radi odnosno djeluje, znanje i razumijevanje.

Glavni model ponašanja je tzv. „ABC model ponašanja" (Health and Safety Executive (HSE), 2002., Robinson, 2013.), a njegovo razumijevanje omogućuje utjecati na promjene u ponašanju. $A B C$ jest akronim od engleskih riječi

- Activator (aktivator)

- Behaviour (ponašanje)

- Consequences (posljedica).

Ovaj model govori da je ponašanje uzrokovano nizom aktivatora te ovisi o posljedicama koje će povećati ili smanjiti vjerojatnost ponavIjanja tog istog ponašanja u budućnosti.

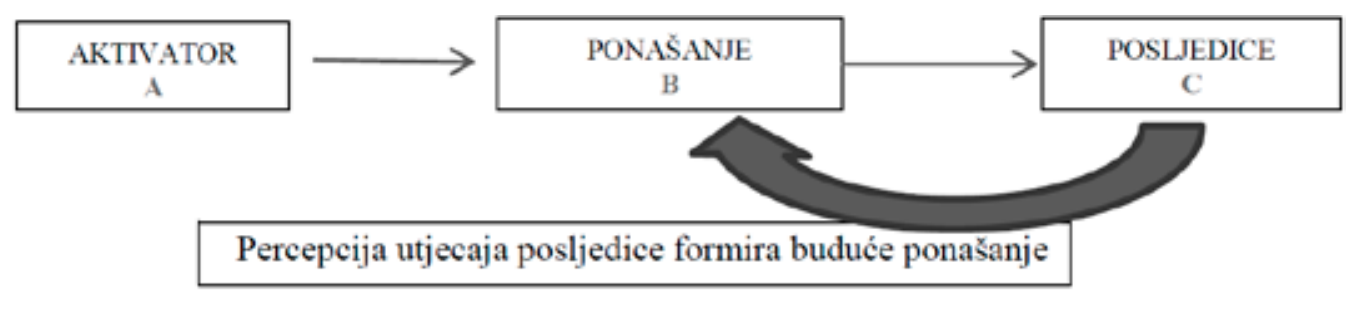

Slika 1. Prikaz ABC modela ponašanja

Figure 1. ABC behavioural model 
Aktivator nastupa prije ponašanja. Primjeri aktivatora u sigurnosti jesu radne upute, odgovarajuća oprema, znakovi sigurnosti, zakonske obveze i slično. Evo primjera jednog ponašanja koji se često viđa na radilištima: nenošenje zaštitnih naočala. To je u ovom primjeru Ponašanje (B=Behavior). Što sve može potaknuti odnosno aktivirati ovo Ponašanje (B)? Neki primjeri su dani u stupcu Aktivator (A) Tablice 1. Naravno lista bi mogla biti puno duža.

Tablica 1. Aktivatori i posljedice određenog ponašanja

Table 1. Activators and consequences of different behaviours

\begin{tabular}{|c|c|}
\hline \multicolumn{2}{|c|}{ PONAŠANJE (B) } \\
\hline \multicolumn{2}{|c|}{ Radnik ne nosi zaštitne naočale } \\
\hline $\begin{array}{l}\text { AKTIVATOR } \\
\text { (A) }\end{array}$ & $\begin{array}{l}\text { POSLJEDICE } \\
\text { (C) }\end{array}$ \\
\hline Izgrebane zaštitne naočale & Ozljeda oka \\
\hline $\begin{array}{l}\text { Zaštitne naočale nisu } \\
\text { dostupne }\end{array}$ & Opomena nadređenog \\
\hline $\begin{array}{l}\text { Drugi radnici ne nose } \\
\text { zaštitne naočale }\end{array}$ & Prilagoditi se kolegama... \\
\hline $\begin{array}{l}\text { Nepoznavanje opasnosti i } \\
\text { rizika }\end{array}$ & \\
\hline
\end{tabular}

lako aktivator potiče određeno ponašanje, njegovo postojanje ne jamči da će se određeno ponašanje i dogoditi. Kako bi se određeni tip (željeni) ponašanja održao, bitno je sagledati posljedice, odnosno kako pojedinac percipira utjecaj posljedice na njega samoga.

Posljedice su definirane kao ishod određenog ponašanja, a utječu na vjerojatnost ponavljanja odnosno održavanja tog istog ponašanja. Dakle, vjerojatnost nekog ponašanja može bit uvećana ili umanjena ovisno o posljedicama koje je ponašanje uzrokovalo, odnosno o percepciji njihovog utjecaja na nas same.

U Tablici 2. prikazane su osnovne značajke, a mogu se nazvati i "karakteristike" posljedica koje utječu na naše ponašanje. Percepciju utjecaja svake posljedice na nas osobno karakteriziraju tri elementa:

- Vrijeme: hoćemo li posljedicu osjetiti na nama uskoro (istog trena, za koju minutu ili najviše sat) ili u neko udaljeno, kasno vrijeme (za nekoliko mjeseci ili godina);

- Vjerojatnost: hoće li naše ponašanje imati sigurno tu posljedicu ili je ona neizvjesna;

- Utjecaj na pojedinca: dobar (ugodan) ili loš ( neugodan).

Tablica 2. Karakteristike Posljedice (C)

Table 2. Characteristics of Consequence (C)

\begin{tabular}{||c|c|c|c||}
\hline $\begin{array}{c}\text { Posljedica } \\
(C)\end{array}$ & Vrijeme & Vjerojatnost & $\begin{array}{c}\text { Utjecaj na } \\
\text { pojedinca }\end{array}$ \\
\hline $\begin{array}{c}\text { značajan } \\
\text { utjecaj na } \\
\text { ponašanje }\end{array}$ & USKORO & SIGURNO & DOBAR \\
\hline $\begin{array}{c}\text { neznatan } \\
\text { utjecaj na } \\
\text { ponašanje }\end{array}$ & KASNIJE & NEIZVJESNO & LOŠ \\
\hline
\end{tabular}

U Tablici 3 dana je tablična analiza percepcije karakteristika pojedinih primjera Posljedica (C) iz Tablice 1. Tako se vidi da u trenutku kada ne nosimo zaštitne naočale na radilištu ne mislimo da ćemo u tom trenutku ozlijediti oko, nismo sigurni da ćemo ga uopće ozlijediti, a i naravno nikome nije ugodno kada se ozlijedi.

Nasuprot tome, ako smo u okruženju gdje mali broj ljudi ili nitko ne nosi zaštitne naočale, u trenutku kada ih niti mi ne nosimo, osjećamo pripadnost skupini ljudi koja nas okružuje, tu smo s njima baš u tom trenutku i to nas čini da se dobro osjećamo.

Tablica 3. Analiza karakteristika Posljedice (C)

Table 3. Characteristics of Consequence Analysis (C)

\begin{tabular}{|c|c|c|c||}
\hline $\begin{array}{c}\text { Posljedica } \\
(C)\end{array}$ & Vrijeme & Vjerojatnost & Utjecaj \\
\hline Ozljeda oka & KASNIJE & $\begin{array}{c}\text { NEIZVJE- } \\
\text { SNO }\end{array}$ & LOŠ \\
\hline $\begin{array}{c}\text { Sukob s } \\
\text { nadređenim }\end{array}$ & KASNIJE & $\begin{array}{c}\text { NEIZVJE- } \\
\text { SNO }\end{array}$ & LOŠ \\
\hline $\begin{array}{c}\text { Prilagoditi } \\
\text { se kolegama }\end{array}$ & USKORO & SIGURNO & DOBAR \\
\hline
\end{tabular}

Ako bi prema tradicionalnom pristupu radnik bio kažnjen zbog nekorištenja zaštitnih naočala, vjerojatno je da bi naočale nakon toga nosio neko određeno vrijeme. No, s vremenom bi zaboravio na posljedicu nenošenja naočala (opomena, ukor) i ponovno bi ih prestao nositi ako 
i drugi koji se tako ponašaju ne bi bili kažnjeni, odnosno ako ne bi bio SIGURAN da će, ako ne nosi naočale, biti kažnjen. Nažalost, u našoj svakodnevnici vjerojatnost da će netko biti opomenut ili kažnjen zbog nepoštovanja pravila sigurnosti na radu je mala, a ako se to i nekad dogodi, onda je to s odmakom.

Da bi posljedica bila učinkovita i utjecala na promjenu u ponašanju, ona mora nastupiti $u$ skoro vrijeme, vjerojatnost nastanka mora biti sigurna, a njezin utjecaj na pojedinca dobar.

Iz navedenog je vidljivo da, ako se želi promijeniti Ponašanje (B), osim promjene nekih od Aktivatora (A); (npr. nedostupnost ili neadekvatnost zaštitnih naočala), prvenstveno se mora promijeniti percepcija karakteristika Posljedica (C) Ponašanja (B). Drugim riječima, ako želimo da SVI radnici na radilištu nose zaštitne naočale, onda njihovo nenošenje mora postati neprihvatljivo i onaj koji ih ne nosi ne smije se osjećati kao dio grupe. Tijekom osposobljavanja za rad na siguran način i kratkih sastanaka prije početka smjene (Tool Box Talks) jasno i primjerom treba objasniti i pokazati koje su posljedice nenošenja zaštitnih naočala. I na kraju, uvijek zasnivajući se na kratkoj listi naših primjera, radnik/zaposlenik mora biti siguran da će ga rukovoditelj opomenuti ako ne bude nosio zaštitne naočale na radilištu. Naravno, pod uvjetom da ih i on sâm uvijek i redovito nosi!

\section{TKO UVODI PROMJENE U KULTURI PONAŠANJA U SIGURNOSTI NA RADU}

Ako se ponašanje odnosno ophođenje spram sigurnosti na radu definira kao doprinos ljudi na stvaranju i obogaćivanju kulture sigurnosti na mjestu rada, očito je da promjene uvode ljudi koji imaju karakteristike vođe (Herrero, Viral, 2006., Schein, 2004.).

Biti vođa u zaštiti na radu ne znači nužno biti na visokoj poziciji u organizaciji, iako to u svakom slučaju pomaže jer je time olakšan utjecaj na veći broj ljudi i sama pozicija omogućava ja- sniji i direktniji „odozgo prema dolje“ utjecaj na radnike. Činjenica je da u zaštiti na radu svatko može i mora biti vođa. Mora jednostavno voditi brigu ne samo o ekstrinzičnim vrijednostima posla koji obavlja u organizaciji u kojoj djeluje (završetak poslova na vrijeme, ambicije, napredovanje na poslu, zarada za sebe i za poduzeće u kojem radi, itd.) nego u isto vrijeme o intrinzičnim vrijednostima, tj. onim vrijednostima koje su to "same po sebi", koje to imaju "u sebi" bez nekog isključivog i direktnog interesa, kao što je to na primjer briga za druge.

Takve osobe, vođe, moraju imati određene karakteristike koje uključuju (Groover, 2016., Schein, 2004.):

- Imati viziju - gledati u budućnost, imati jasnu sliku kakav se oblik i sustav zaštite na radu želi postići, ciljeve kako do njega doći te alate kako te ciljeve i ostvariti;

- Biti fokusiran na tematiku zaštite na radu uvijek govoriti, opažati, djelovati, ponašati se u skladu s pravilima i načelima zaštite na radu, stavljati ju na prvo mjesto te ju nikada ne zapostaviti;

- Imati utjecaj i biti nadahnuće drugima - nije nužno biti "šef" kako bi se imalo utjecaja. Posjedovati primjereno znanje za svoj posao i dijeliti ga s drugima, biti otvoren prema drugima, znati razumjeti tuđe probleme i podržati ih u njima, biti strastven u svojem poslu te znati motivirati druge da i oni to postanu;

- Biti uvjerljiv i dosljedan - ponašati se u skladu s pravilima koje promovira i propagira, ili kako se to kaže na engleskom "walk the talk". Veći utjecaj na okolinu ima naše ponašanje nego naše riječi, a pogubno na naš kredibilitet djeluje ako naše ponašanje nije u skladu s našim riječima;

- Raditi u timu - pravi vođa ne radi sam nego uvijek u timu koji može voditi. No, svakom članu tima mora dati povjerenje i određenu slobodu u iznošenju prijedloga i izvršenju zadataka. Uspjeh nije zasluga pojedinca, nego grupe ljudi u kojoj taj isti djeluje; 
- Učinkovito komunicirati - ne samo jasno iznositi svoje ideje i misli već i jednako tako dopustiti drugima da iznesu svoje. Učinkovito komunicirati znači znati dobro slušati i poticati dvosmjernu komunikaciju. Valja upozoriti, ali jednako tako i dopustiti biti upozoren;

- Dati povratnu informaciju i nagrađivati - razgovarati o postignutim rezultatima, ali i o problemima, dijeliti informacije sa svojim suradnicima, odgovarati na postavljene izazove, intervenirati kada je to nužno, ali jednako tako i pohvaliti i/ili nagraditi one koji postižu dobre rezultate, koji svojim postupcima pridonose unapređenju zaštite na radu, koji mijenjaju na bolje svoju osobnu kulturu zaštitite na radu.

Jasno je da su vođe oni koji započinju i prvi prihvaćaju val promjena u kulturi, pa tako i u kulturi zaštite na radu. No, sami ne mogu učiniti baš puno. Da bi se dogodile promjene u kulturi jedne zajednice, potrebno je da tu promjenu prihvati najmanje $60 \%$ njezinih članova (Sharman, 2016.). Stoga jednaku važnost s vođama imaju kako "rani“ tako i "kasni“ prihvatitelji. Za razliku od prvih kojima je dovoljno nekoliko situacija, dokaza kako bi ih shvatili kao korisne predložene i provedene promjene, potonjima je potreban izvjestan vremenski rok i više "argumenata" da ih prihvate. Bitno je napomenuti da uvijek postoje osobe koje će pružati otpor promjenama, ali pokazalo se da takva skupina s vremenom nestaje te da velika većina prihvati nastale promjene.

Koja je uloga stručnjaka zaštite na radu u promjeni kulture? On u ovim promjenama mora sudjelovati kao vođa, primjer i voditelj. No, kako bi cijeli proces dobio na vjerodostojnosti i bio uistinu uspješan, stručnjak zaštite na radu mora nadasve biti savjetnik, motivator i moderator promjena vrhovnog rukovodstva odnosno uprave kompanije i/ili radilišta koji prvi svojim primjerom mora pokazati navedene karakteristike vođe u stvaranju primjerene/kulture sigurnosti na radu.

\section{ALATI ZA PROMJENE U PONAŠANJU}

Kao što je već navedeno, za promjenu kulture nužno je intervenirati. Parafrazirajući Einsteina, ne možemo misliti, raditi i djelovati na isti način, a očekivati da se dogode promjene. Kako bi se promijenilo ponašanje radnika, u ovom slučaju na bolje, te kako bi se unaprijedila kultura sigurnosti na radu, nužno je, osim znanja, motiviranosti i odgovarajućih vještina, imati hrabrosti intervenirati u svakom slučaju kada se primijeti rizična situacija ili nečije rizično ponašanje. No, svjesni smo da to nije uvijek lako, poglavito ako bi se trebalo ili željelo intervenirati spram kolega i/ili nadređenih. Alat koji je Saipem razvio i uspostavio kako bi olakšao intervencije unutar radnog okoliša, a i šire, te time omogućio i ubrzao promjene u kulturi sigurnosti na radu nazvan je "5 (five) STARS“ kao akronim engleskih izvedenica procesa same intervencije, Start, Target, Agree, Reason, Self Impact (Deal with it training, 2017.).

Program „5 Stars“ predstavlja jednu od tehnika kako intervenirati u slučaju uočavanja nesigurnog ponašanja, a značenje pojedinih riječi u njegovom kontekstu dano je u Tablici 4. 
Tablica 4. Alat za intervenciju "5 STARS“

Table 4. "5 STARS" intervention tool

\begin{tabular}{||l|l||}
\hline \hline Start & $\begin{array}{l}\text { Započni intervenciju - predstavi se, započni razgovor, budi uljudan, ne viči niti podiži glas. Sam početak na- } \\
\text { ravno ovisi i o odnosima koje imamo s osobom spram koje smo započeli intervenciju. }\end{array}$ \\
\hline Target & $\begin{array}{l}\text { Ciljaj uvijek na postupak nikada na osobu. Cilj intervencije nikada ne smije biti direktno osoba koja se ponaša } \\
\text { na nesiguran način. To bi ga na neki način zastrašilo i uvjetovalo bi stvaranje otpora i odbojnosti spram inter- } \\
\text { vencije i promjene. Ista mora biti usmjerena prema postupku, načinu obavljanja posla i radnih zadataka koji se } \\
\text { u danom momentu izvode na način rizičan za pojedinca ili za druge kolege na poslu. }\end{array}$ \\
\hline Agree & $\begin{array}{l}\text { Dogovori i složi se oko ispravnog obavljanja posla. Zajednički nađite odgovor i rješenje kako se taj isti posao } \\
\text { može obaviti na sigurniji način, u skladu s pravilima struke, zakonskim aktima, pravilima kompanije, ranijim } \\
\text { iskustvima, procedurama, dostupnom ili predviđenom zaštitnom opremom, itd. }\end{array}$ \\
\hline Reason & $\begin{array}{l}\text { Pokušaj saznati i razumjeti, te usuglasiti razlog ili razloge zbog kojeg/kojih je osoba izvršavala svoje radne za- } \\
\text { datke na nesiguran način. Npr. nedostatak vremena, nedostatno osposobljavanje, nedostatak adekvatne opreme } \\
\text { ili alata, zanemarivanje pravila zaštite na radu... }\end{array}$ \\
\hline Self-impact & $\begin{array}{l}\text { Utjecaj na osobu - upitaj kako bi se negativne posljedice rada na nesiguran način potencijalno odrazile na } \\
\text { samu osobu, na njegov fizički integritet (npr. ozljeda oka, gubitak vida, nesposobnost za rad, itd.). Navedi neke } \\
\text { slične primjere ako ih znaš! }\end{array}$ \\
\hline
\end{tabular}

Važno je istaknuti da se promjena ponašanja, a s time i dugoročna promjena kulture, ne dešava samo ispravljanjem negativnih primjera nego, ako ne i poglavito, isticanjem dobrih. Stoga je nužno i pohvaliti sve one koji se u izvođenju svojih radnih zadataka ponašaju u skladu sa svim pravilima sigurnosti na radu. Za takav tip intervencije jednako tako primjenjuje se "5 STARS" alat, s time da je "Reason“ (Razlog) zamijenjen $\mathrm{s}$ "Recognise" (Pohvali), tj. pohvali način rada i ponašanje pojedinca. Ta pohvala, pogotovo ako je javna, primjerena i ako je osoba sigurna da će se dogoditi uvijek kada nešto dobro i ispravno napravi, uvelike utječe na promjenu ponašanja i kulture jer „prepoznavanje primjerenog ponašanja“ (npr. nošenje zaštitnih naočala, uz svu ostalu zaštitnu opremu) u sklopu percepcije posljedice ponašanja dobiva karakteristiku "Uskoro, Sigurno, Dobro", a time i uvjetuje naše buduće ponašanje.

Bitno je istaknuti da je prilikom intervencija važno tko spram koga intervenira. Je li intervencija usmjerena samo od rukovoditelja prema radnicima ili se potiče komunikacija u oba smjera. Svima mora biti dana ne samo sloboda nego i obveza intervencije u bilo kojem smjeru, pa tako i ona "odozdo prema gore" odnosno od radnika prema rukovoditeljima ako se oni ne ponašaju u skladu s mjerama sigurnosti na radu ili čak traže da ih radnici ne poštuju ili zaobilaze kako bi se eventualno u danom trenutku uštedjelo na vre- menu ili novcu. Uspješnost ovog alata pokazala se najboljom kod intervencija koje su došle od kolega (,peer-to-peer").

\section{PRIMJENA U PRAKSI}

Program promjena ponašanja i osnaživanja kulture sigurnosti i zaštite zdravlja na radu započeo je 2007. godine u Saipemu na korporativnoj razini programom pod nazivom "Leadership in Health and Safety" (LiHS). Do sada je razvijeno pet faza programa:

1. "The Safer the Better" - radionica u trajanju od jednog i pol dana namijenjena uglavnom rukovoditeljima na svim razinama. Radionice vode za to posebno osposobljeni voditelji.

2. "Cascading" - radionice u trajanju od oko dva i pol sata namijenjene svim radnicima, a održavaju ih u svojim jedinicama rukovoditelji koji su sudjelovali na LiHS radionicama prve faze.

3. "5 STARS Training" - podučavanje određenog broja radnika u korištenju ranije spomenutog alata za intervencije od za to osposobljenih trenera. Zaposlenici odabrani za ovo osposobljavanje unutar organizacije su prepoznati kao lideri u sigurnosti na radu koji mogu utjecati na širenje i kreiranje kulture zaštite na radu. Ovaj 
oblik osposobljavanja isključuje stručnjake zaštite na radu i djelatnike odjela sigurnosti na radu.

4. "Leading behaviors" - pet osnovnih pravila glede ponašanja u zaštiti na radu i oko nje čije se poštovanje i dosljedna primjena očekuje od svih radnika. Svako od pravila zasebno je prezentirano u odvojenim izlaganjima, a u dodatnoj sekciji sažete su osnovne poruke.

5. "Choose life" - program u cijelosti posvećen zdravlju, rizicima u vezi s nekim najčešćim obolijevanjima, njihovom smanjenju te buđenju osobne odgovornosti svakog pojedinca za očuvanje vlastitog zdravlja. Namijenjen je svim radnicima i predstavlja se na za to namijenjenim sastancima u trajanju od oko 90 minuta.

Saipem S.p.A Croatian Branch (SACRO) provodi sve faze programa i osposobljavanja svojih radnika od 2008. godine. Od tada do danas održane su brojne radionice. Prosječno se osposobljavanje radnika o pitanju interveniranja u sigurnosti održava svaka tri mjeseca. SACRO je tijekom posljednjih osam godina prosječno imao 307 zaposlenika, a njihov broj varirao je od 232 do 342 .

LiHS fazu 1 - "The Safer the Better" i/ili LiHS fazu 2 - "Cascading“ završilo je 398 radnika u 27 radionica.

Održane su četiri radionice "5 STARS Training" koje je pohađalo ukupno 66 zaposlenika.

"Choose life" program pohađalo je 303 radnika u 18 radionica, dok je "Leading behaviors" program još u tijeku i do sada je 277 radnika u 48 radionica sudjelovalo na svih šest programom predviđenih prezentacija.

Valja napomenuti da su neki od zaposlenika pohađali navedene tečajeve za vrijeme njihovog izaslanstva izvan matične ustanove, odnosno u drugim kompanijama unutar Saipem Grupe. Broj tih zaposlenika kao i odnosne radionice/sekcije nisu uračunate u navedene aktivnosti, no jednako pridonose poboljšanju kulture sigurnosti na radu u SACRO-u.
Jedan od rezultata provedenih osposobljavanja i kampanja je da od 2008. godine, s odrađenih oko 6 milijuna radnih sati, u Saipem S.p.A Croatian Branch nije zabilježena niti jedna ozljeda na radu

\section{ZAKLJUČAK}

Neprekidnim ulaganjem u radnu opremu, znanje, vještine i motiviranost radnika stvaraju se pozitivne promjene u ponašanju radnika naspram sigurnosti na radu. Stvaranje kulture sigurnosti na radu važno je kako za radnike tako i za njihove obitelji, samu kompaniju i naposljetku društvo u cjelini. Stvaranje kulture sigurnosti na radu dugotrajan je proces, a kako bi se došlo do željenog cilja potrebno je djelovati kako na ponašanje radnika tako i na njihovo radno okruženje. Vodeću ulogu u tom procesu imaju vođe koji svojim djelovanjem, utjecajem, ponašanjem, znanjem, vještinama i hrabrošću u intervencijama pokreću promjene.

\section{LITERATURA}

Deal with it training, dostupno na: http:// www.dealwithittraining.co.uk/the-differencebetween-safety-culture-and-safety-climate/, pristupljeno: 29.1.2017.

Groover, D.: Seizing moments of transformation in safety: Changing the culture by changing the experience, dostupno na: http://www. safetyandhealthmagazine.com/articles/12818safety-leadership-seizing-moments-of-transformation-in-safety-changing-the-cultureby-changing-the-experience, pristupljeno: 19.5.2016.

Herrero, L., Viral, C.: The Alternative to Slow, Painful and Unsuccessful Management of Change in Organisations; meetingminds UK, 2006.

Health and Safety Executive (HSE), The Keil Center Strategies to promote safe behaviour as part of a health and safety management system, Contract research report 430/2002. 
Robinson, Keith D.: Influencing Behaviors for Better Safety Performance, Posted March 11-13, 2013 In Indiana Safety and Health Conference 7 Expo, dostupno na: http://www.insafetyconf. com/media/PDF/safety_conf_2013/session-materials/SC6.pdf, pristupljeno: 19.5.2016.

Schein, E.: Organizational Culture and Leadership, 3rd edition, The Jossey Bass, San Francisco CA, 2004.
Sharman, A.: Catching the safety virus: the power and potency of social contagion, dostupno na: http://www.shponline.co.uk/ catching-the-safety-virus-the-power-andpotency-of-social-contagion/, pristupljeno: 30.5.2016.

Static document, dostupno na: http://www. saipem.com/en_IT/static/documents/1876spm_ brochureLIHS.pdf, pristupljeno: 19.5.2016.

\section{LEADERSHIP AND INTERVENTION IN BEHAVIOUR AS A WAY TO IMPROVE SAFETY-AT-WORK CULTURE}

SUMMARY: National legislation and regulations, various standards and management systems and numerous work instructions all serve to define rules for safe behaviour at work. Nevertheless, accidents at work continue to happen and their main cause is non-compliance with prescribed safety rules.

The question is why employees at all levels, in spite of their awareness of safety rules, still decide to behave in an unsafe manner, and what we can do to change employee behaviour, the working community and the culture of safety at work in general.

The authors explain the behavioural model and the consequences of unsafe behaviour as well as the role of leadership in the development of positive changes in safety at work. Furthermore, they inform us on the tools used in safe behaviour campaigns, with special emphasis on the importance of intervening in non-safe behaviours and/or non-safe situations.

Key words: safe behaviour, leader, intervention 